\title{
PENGARUH STRATEGI PEMBELAJARAN DAN KOMUNIKASI INTERPERSONAL TERHADAP HASIL BELAJAR PUBLIC RELATIONS MAHASISWA
}

\author{
Ayunda Sabrina Sormin \\ Universitas Muhammadiyah Tapanuli Selatan \\ Aznindya_fitry@yahoo.com
}

\begin{abstract}
Abstrak: Penelitian ini bertujuan untuk mengetahui hasil belajar public relations mahasiswa yang diajarkan menggunakan strategi pembelajaran mind mapping lebih tinggi daripada hasil belajar mahasiswa yang diajarkan dengan menggunakan strategi pembelajaran ekspositori, serta interaksinya. Teknik pengambilan sampel digunakan dengan Cluster Random Sampling berdasarkan komunikasi interpersonal, sehingga sampel penelitian ini pada kelompok pembelajaran masing-masing terdiri dari 37 untuk eksperimen dan 37 orang untuk kelompok kontrol. Metode penelitian yang digunakan adalah quasi eksperimen dengan faktorial $2 \times 2$. Teknik analisis yang digunakan adalah analisis varian dua jalur dengan taraf signifikansi $\alpha=0,05$ dengan Uji F,Uji Barlett pengujian lanjut menggunakan Uji Scheffe. Hasil penelitian menunjukkan hasil belajar public relations mahasiswa yang diajar dengan menggunakan strategi pembelajaran mind mapping lebih tinggi daripada hasil belajar public relations yang diajar dengan menggunakan strategi pembelajaran ekspositori dengan $F_{h}=7,38, F_{t}=3,98$ dengan $d k(1,70)$ didapat $F_{h}(7,38)>F_{t}(3,98)$, Hipotesis telah teruji kebenarannya sehingga Ha diterima dan Ho ditolak.
\end{abstract}

Kata Kunci : Public Relations, Mind Mapping, Ekspositori.

Abstract: This study aims to determine public relations student learning outcomes are taught using mind mapping learning strategy is higher than the learning outcomes of students who are taught using expository learning strategy, and the interaction. The sampling technique used by cluster random sampling based on interpersonal communication, so that the study sample in each study group consisted of 37 to 37 people for the experimental and control groups. The method used is a quasi experiment with $2 \times 2$ factorial analysis technique used is the analysis of variance of two lanes with a significance level $\alpha=0.05$ by $F$ test, further testing Barlett test using Scheffe test. Results showed (1) Results of studying public relations students taught using mind mapping learning strategy is higher than the results of studying public relations taught using expository teaching strategy with $F c=6,79, \quad F t=3.98$ with $d f(1,70)$ obtained Fh (7.38)> Ft (3.98), hypothesis has been verified that Ha Ho accepted and rejected.

Key Words :Public Relations, Mind Mapping, Ekspositori

\section{PENDAHULUAN}

Public relations (PR) atau kadang disebut dengan istilah hubungan masyarakat (HUMAS) memiliki posisi yang sangat penting dalam sebuah organisasi, terutama bila organisasi tersebut sering berinteraksi dengan masyarakat luas Widyahartono (2011) menyatakan bahwa relasi pemerintah baik pusat ataupun daerah, akademisi / masyarakat intelektual ataupun mahasiswa seringkali merasa "hambar" dan merasa satu arah dalam pertanggungjawaban social ( stakeholders responsive). Dalam Pemerintahan Politik sendiri, seringkali tidak terjadi keterbukaan terhadap penyelenggaraan kegiatan yang dilakukan. Hal ini erat kaitannya dengan rendahnya peran public relations. Interaksi yang terjadi pada saat ini dalam proses public relations sangatlah formal dan terstruktur, keluwesan dan komunikasi dua arah tidak tampak bahkan terkesan kaku.

Rendahnya mutu pembelajaran sebagaimana diuangkapkan diatas juga terjadi pada mata Rendahnya mutu pembelajaran sebagaimana diuangkapkan diatas juga terjadi pada mata kuliah public relations. Hal ini dapat dilihat dari kurun waktu lima tahun terakhir mulai tahun 2009-2013 lulusan Fakultas Dakwah hanya sekitar 20\% yang mampu terjun ketengah-tengah masyarakat menjadi Public 
Relation Officer / Public Speaker atau dengan kata lain Ustadz / Ustadzah yang menjadi penyampai informasi keislaman sesuai dengan tujuan Fakultas Dakwah IAIN Padang Sidempuan yaitu, (1) Terwujudnya keunggulan akademik dalam bidang Dakwah dan Komunikasi secara profesional yang dilandasi oleh akhlakul karimah yang dijiwai oleh alQuran dan Sunnah, (2) Tercapainya potensi akademik mahasiswa yang berdimensi keilmuan Dakwah dan Komunikasi, serta mampu mengaktualisasikan dalam kehidupan masyarakat yang dilandasi nilai-nilai akhlakul karimah, dan (3) Menghasilkan sarjana muslim yang ahli dalam bidang Dakwah dan Komunikasi, professional, dan bertanggung jawab dalam mewujudkan masyarakat yang berperadaban tinggi yang dijiwai oleh al-Quran dan sunnah. Berdasarkan data yang peneliti peroleh dari Fakultas Dakwah IAIN Padang Sidempuan pada tahun ajaran 2012-2013 ratarata hasil belajar mahasiwa pada mata kuliah public relations adalah 76,22 , nilai ini masih tergolong belum maksimal karena masih dibawah kategori kriteria ketuntasan minimal (KKM) mata kuliah public relations yaitu 78,00 .

Hamalik (2004:18) menjelaskan faktor yang mempengaruhi hasil belajar yaitu: (1) penggunaan metode mendegarkan dan resitasi yang dianggap sebagai pemborosan, (2) tugastugas konvensional yang diberikan tidak menentu / tidak jelas, (3) pembelajaran berpusat pada kata-kata tidak memperhatikan makna,(4) mementingkan sejumlah factor yang kurang berarti, (5) kurang menggunakan media dan alat belajar yang konkret, (6) kurang berhasil mengkorelasikan pembelajaran dengan pusatpusat minat,(7) minim melaksanakan kegiatan kerja sama kelompok, (8) penggunaan metode mengajar yang tidak serasi (bersifat tirani) sehingga menimbulakn pengaruh buruk terhadap mahasiswa, (9) kurang memanfaatkan kegiatan-kegiatan belajar diluar kampus, (10) kurang mampu mengadakan penilaian secara tepat dan objektif terhadap kemajuan siswa.

Belum maksimalnya hasil belajar public relations mahasiswa Fakultas Dakwah IAIN Padang Sidempuan disinyalir karena selama ini proses pembelajaran kurang mendukung penguasaan materi,teori dan praktek dari mahasiswa. Berbagai teori yang ada dalam perkuliahan diterima mahasiswa tanpa mereka mampu mengingat materi tersebut untuk kembali disampaikan dan digunakan ditengah- tengah masyarakat. Terlalu banyank materi yang dipelajari dan pembelajaran menekankan pada aspek hafalan yang berorientasi pada pembelajaran konvensional. Pembelajaran yang cenderung tidak berpihak pada cara kerja otak. Serta membuat mahasiswa seringkali malas dan takut untuk menyampaikan materi dengan bahasa mereka sendiri karena materi cenderung monoton dan tidak mengembangkan kreativitas mahasiwa.

Strategi pembelajaran yang digunakan selama ini seringkali menimbulkan kebosanan, menumpuk informasi dalam otak siswa tanpa memberikan tekhnik menyimpannya menjadi long term memory, serta kurang mengembangkan kreativitas mahasiswa yang berakibat rendahnya hasil belajar. Untuk mengurangi atau bahkan menghindari strategi pembelajarn tersebut diupayakan strategi pembelajaran yang lebih efektif dalam menciptakan komunikasi multi arah, sehingga menciptakan interaksi yang kondusif dalam proses pembelajaran. Namun perlu disadari, bahwa strategi tidak ada yang buruk atau terlalu baik, karena setiap strategi memiliki kekurangan dan kelebihan. Seperti yang diungkapkan Sudjana (2002:76) bahwa setiap metode mengajar memiliki kekurangan dan kelebihan.

Trianto (2009:17) Pembelajaran adalah usaha sadar dari guru untuk membelajarkan siswanya yaitu mengarahkan interaksi siswa dengan sumber belajar lainnya dalam rangka mencapai tujuan yang diharapkan. Dengan demikian melalui kegiatan pembelajaran individu akan mengalami perubahan perilaku berupa pengetahuan, sikap, dan keterampilan. Pengetahuan menunjuk pada informasi yang tersimpan dalam pikiran, sikap adalah kemampuan seseorang menerima dan menolak objek berdasarkan penilaian terhadap objek tersebut, sedangkan keterampilan adalah suatu tindakan atau tingkah laku yang mampu diperlihatkan peserta didik sebagai tanda bahwa peserta didik tersebut telah belajar.

Mulyati (2005:5) menjelaskan bahwa belajar adalah merupakan usaha sadar individu untuk mencapai tujuan peningkatan diri atau perubahan diri melalui latihanlatihan dan pengulangan-pengulangan serta perubahan yang terjadi bukan karena kebetulan. Hamalik (2003:36) menjelaskan 
belajar adalah modifikasi atau memperteguh kelakuan melalui pengalaman.

Djamarah dan Zain (2002:59) menjelaskan bahwa hasil belajar adalah penguasaan peserta didik terhadap bahan / materi pelajaran yang telah diberikan ketika proses mengajar berlangsung. Gagne dan Briggs (1979) mengemukakan bahwa hasil belajar dapat dikelompokkan kedalam lima kategori, yaitu keterampilan intelektual, strategi kognitif, informasi verbal, kemampuan motorikmdan sikap.

Romizowski (1981:157) menyatakan bahwa hasil belajar diperoleh dalam bentuk pengetahuan dan keterampilan. Pengetahuan dikelompokkan kedalam empat kategori yaitu fakta, konsep, prosedur dan prinsip. Fakta merupakan pengetahuan tentang objek nyata yang merupakan asosiasi dari kenyataankenyataan dan informasi verbal suatu objek, peristiwa dan manusia. Konsep merupakan pengetahuan tentang seperangkat objek konkrit atau definisi. Prosedur merupakan pengetahuan tentang tindakan demi tindakan yang bersifat linear dalam mencapai suatu tujuan. Sedangkan Prinsip adalah merupakan pernyataan mengenai hubungan dua konsep atau lebih, hubungan itu bisa bersifat kausalitas, korelasi atau aksiomatis.Keterampilan dikelompokkan kedalam empat kategori yaitu keterampilan kognitif,acting, reacting dan interaktif. Keterampilam berkaitan dengan keterampilan individu dalam menggunakan pikiran dan menghadapi suatu situasi atau dalam artian nilai-nilai emosi dan perasaan. Keterampilan reacting dimaknai dengan sikap.Keterampilan interaktif adalah keterampilan seseorang dalam berhubungan dengan orang lain untuk mencapai suatu tujuan seperti komunikasi,persuasif dan pendidikan.

Public relations yang diterjemahkan menjadi hubungan masyarakat (humas) mempunyai dua pengertian. Pertama, humas dalam artian sebagai teknik komunikasi atau technique of communication dan kedua, humas sebagai metode komunikasi atau method of communication (Abdurrahman, 1993: 10). Konsep public relations sebenarnya berkenaan dengan kegiatan penciptaan pemahaman melalui pengetahuan, dan melalui kegiatan-kegiatan tersebut akan muncul perubahan yang berdampak ( Jefkins, 2004: 2).

Public relations menyangkut suatu bentuk komunikasi yang berlaku untuk semua organisasi (non profit - komersial, publikprivat, pemerintah - swasta). Artinya public relations jauh lebih luas ketimbang pemasaran dan periklanan atau propaganda, dan telah lebih awal. Hubungan dengan masyarakat luas baik melalui publisitas khususnya fungsi-fungsi organisasi dan sebagainya terkait dengan usaha menciptakan opini publik dan citra yang menyenangkan untuk dirinya sendiri.. Moore (2004:6) menyatakan public relations adalah Filsafat sosial dan manajemen yang dinyatakan dalam kebijaksanaan beserta pelaksaannya yang melalui interpretasi yang peka mengenai peristiwa-peristiwa berdasarkan pada komunikasi dua arah dengan publiknya, berusaha memperoleh saling pengertian dan itikad baik.

Mata kuliah public relations diberikan dengan mengikuti tuntunan bahwa menyampaikan dakwah kepada manusia memerlukan keahlian dalam menjalin komunikasi dengan masyarakat serta mampu berupaya memberikan informasi atau pesanpesan sesuai dengan tujuan dan kebijaksanaan instansi / lembaga kepada masyarakat sebagai khalayak sasaran, sedangkan ke dalam wajib menyerap reaksi, aspirasi atau opini khalayak tersebut di serasikan demi lembaga pendidikan. Tuntutan visi ini mendorong dikembangkannya standar kompetensi sesuai dengan jenjang perkuliahan yang secara nasional ditandai dengan ciri-ciri : (1) lebih menitikberatkan kepada pencapaian kompetensi secara utuh selain pencapaian materi, (2) mengakomodasikan keragaman dan kebutuhan masyarakat, (3) memberikan kebebasan yang lebih luas kepada pendidik di lapangan untuk mengembangkan strategi dan program pembelajaran sesuai dengan kebutuhan dan ketersediaan sumber daya pendidikan.

Melalui pembelajaran public relations diharapkan akan membantu dan mendukung visi dan misi serta tujuan fakultas dakwah IAIN Padang Sidempuan yaitu, Sebagai pusat pengembangan akademik khususnya dalam kajian Ilmu Dakwah dan Ilmu Komunikasi yang dilandasi dengan nilai-nilai akhlakul karimah yang dijiwai oleh al-Quran dan Sunnah. Misinya yaitu,(1) Meningkatkan kualitas akademik dalam bidang dakwah dan komunikasi secara profesional yang dilandasi oleh semangat uswatun khasanah , (2) Mengembangkan potensi dan kapasitas keilmuan dakwah dan Komunikasi kearah terwujudnya sarjana muslim yang cerdas, 
profesional, terampil, bertanggung jawab dan memiliki akhlakul karimah, (3) Mewujudkan sarjana dakwah dan Komunikasi yang berdaya saing tinggi, berperadaban dalam bidang Dakwah dan Komunikasi, serta tujuannya yaitu,(1) Terwujudnya keunggulan akademik dalam bidang Dakwah dan Komunikasi secara profesional yang dilandasi oleh akhlakul karimah yang dijiwai oleh al-Quran dan Sunnah, (2) Tercapainya potensi akademik mahasiswa yang berdimensi keilmuan Dakwah dan Komunikasi, serta mampu mengaktualisasikan dalam kehidupan masyarakat yang dilandasi nilai-nilai akhlakul karimah, (3) Menghasilkan sarjana muslim yang ahli dalam bidang Dakwah dan Komunikasi, professional, dan bertanggung jawab dalam mewujudkan masyarakat yang berperadaban tinggi yang dijiwai oleh al-Quran dan sunnah .

Romizowski (1981) berpendapat bahwa strategi pembelajaran merupakan suatu pendekatan menyeluruh yang dapat dibedakan menjadi dua strategi dasar, yaitu ekspositori ( penjelasan ) dan inkuiri / diskoveri ( penemuan ).Kedua strategi ini dapat dipandang sebagai ujung yang sejalan dalam suatu kontinum strategi.Hal ini erat sekali kaitannya dengan pendekatan deduktif dimana strategi ini dimulai dengan penyajian informasi mengenai prinsip atau kaidah kemudian diikuti dengan tes penguasaan dan penerapan dalam bentuk contoh dan penerapan pada situasi tertentu , sedangkan strategi inkuiri didasarkan pada teori belajar pengalaman yang disebut juga teori belajar pengalaman.

Merill (1981) mengklafisikasikan strategi pembelajaran atas tiga dasar (1) tujuan pengajaran meliputi sepuluh kombinasi antara jenis materi dan tingkah laku yang diharapkan, (2) cara mempresentasikan materi yaitu dari tingkat yang khusus ke tingkat yang umum atau sebaliknya dari tingkat yang umum ke tingkat yang khusus, dan (3) bentuk respon peserta didik dibedakan atas strategi ekspositori dan inkuiri. Romizowski (1981) menekankan bahwa setiap strategi pembelajaran yang dikembangkan selalu mencerminkan posisi teoritis yang dianut tentang bagaimana seharusnya pembelajaran itu dilaksanakan. Oleh karena itu, tenaga pengajar sebagai penyelenggara kegiatan pembelajaran dituntut mampu mengupayakan terjadinya interaksi peserta didik dengan komponen sistem pembelajaran lain secara optimal. \begin{tabular}{llr} 
Dalam & \multicolumn{2}{c}{ menggunakan strategi } \\
pembelajaran hal utama yang harus
\end{tabular} diperhatikan adalah karakteristik peserta didik. Seels dan Richey (1994) berpendapat bahwa karakteristik peserta didik adalah segi latar belakang pengalaman yang berpengaruh terhadap efektivitas proses belajarnya. Dick dan Carey (1996) menjelaskan bahwa dalam pengembangan pembelajaran penting sekali mempertimbangkan karakteristik peserta didik untuk memilih pendekatan yang sesuai dalam kegiatan pembelajaran.Langkah-langkah yang ditempuh sebagai prosedur desain dan pengembangan pembelajaran, yaitu : (1) analisi kebutuhan untuk mengindentifikasi tujuan pembelajaran umum,(2) melakukan analisis intruksional, (3) menganalisis karakterisitik peserta didik dan konteks, (4) pengembangan instrument penilaian, (5) mengembangkan strategi pembelajaran, (6) mengembangkan dan memilih bahan-bahan pembelajaran, (7) merancang dan mengevaluasi formatif pembelajaran, (8) merancang dan mengevaluasi sumatif pembelajaran, (9) revisi untuk setiap langkah penegmbangan pembelajaran.

Reigeluth (1983) menjelaskan tiga komponen utama dalam pembelajaran, yaitu : metode, kondisi dan hasil. Metode pembelajaran adalah berbagai macam cara untuk mencapai berbagai macam hasil ,dalam berbagai kondisi.Kondisi pengajaran merupakan factor yang mempengaruhi dampak metode, dank arena itu penting untuk menentukan metode. Hasil pengajaran merupakam berbagai akibat yang dapat dipakai untuk mengukur kegunaan berbagai macam metode dalam berbagai kondisi.

Mind mapping ditemukan dan dikembangkan Tony Buzan seorang peneliti Inggris yang mengaplikasikan pengetahuan tentang otak dan proses berfikir dalam berbagai bidang kehidupan. Buzan menjelaskan mind mapping sebagai cara termudah menempatkan informasi ke dalam otak dan mengambil informasi keluar dari otak, cara mencatat kreatif, efektif, secara harafiah memetakan pikiran-pikiran kita dengan sangat sederhana (Khan 2010:31). Mind mapping melibatkan kedua sisi otak karena menggunakan gambar, warna, imajinasi (wilayah otak kanan) bersamaan dengan kata, angka dan logika (wilayah otak kiri). Semua gagasan dalam mind mapping berkaitan, membantu otak membuat lompatan pengertian dan imajinasi besar melalui asosiasi (Buzan 2011:60). Mind 
mapping membantu kita belajar, menyusun, menyimpan sebanyak mungkin informasi, mengelompokkannya dengan cara alami, memberi kita akses mudah dan langsung (ingatan yang sempurna pada apapun yang kita pelajari).

Buzan (1993) mengemukakan, bahwa A Mind Map is powerful graphic technique which provides a universal key to unlock the potential of the brain. It harnesses the full range of cortical skills - word, image, number, logic, rhythm, colour and spatial awareness in a single, uniquely powerful manner. In so doing, it give you a freedom to roam the infinite expanses of your brain. Dari pengertian tersebut, dapat disimpulka bahwa Peta Pikiran merupakan suatu teknik grafik yang sangat ampuh dan menjadi kunci yang universal untuk membuka potensi dari seluruh otak, karena menggunakan seluruh keterampilan yang terdapat pada bagian neo-korteks dari otak atau yang

Makin banyak hubungan antar sel yang terjadi, makin cerdas seseorang. Makin sering dan banyak hubungan antara otak kiri dan kanan, makin cerdas dia. Makin erat hubungan kata dengan warna, logika dengan ritme, makin mudah manusia belajar. Itulah dasar teori dari mind mapping. Mind mapping juga dapat mengefisienkan penggunaan waktu dalam mempelajari suatu informasi. Hal ini utamanya disebabkan karena mind mapping dapat menyajikan gambaran menyeluruh atas suatu hal, dalam waktu yang lebih singkat. Dengan kata lain, mind mapping mampu memangkas waktu belajar dengan mengubah pola pencatatan linear yang memakan waktu menjadi pencatatan yang efektif yang sekaligus langsung dapat dipahami oleh individu. Menurut Yovan (2008), keutamaan metode pencatatan menggunakan mind mapping, antara lain: (1) tema utama terdefenisi secara sangat jelas karena dinyatakan di tengah, (2) level keutamaan informasi teridentifikasi secara lebih baik, (3) Informasi yang memiliki kadar kepentingan lebih diletakkan dengan tema utama (4) hubungan masing-masing informasi secar a mudah dapat segera dikenali (5) lebih mudah dipahami dan diingat, (6) informasi baru setelahnya dapat segera digabungkan tanpa merusak keseluruhan struktur mind mapping, sehingga mempermudah proses pengingatan, (7) masing-masing mind mapping sangat unik, sehingga mempermudah proses pengingatan mempercepat proses pencatatan karena hanya menggunakan kata kunci.

Strategi pembelajaran ekspositori adalah strategi pembelajaran yang menekankan kepada proses penyampaian materi secara verbal dari seorang guru kepada sekelompok siswa dengan maksud agar siswa dapat menguasai materi pelajaran secara optimal. Strategi ini merupakan bentuk pembelajaran yang berorientasi kepada guru ( teacher centered approach). Dikatakan demikian karena dalam pembelajaran ini guru memegang peranan yang sangat dominan. Guru menyampaikan materi pembelajaran secara berstruktur dengan harapan materi pelajaran yang disampaikan itu dapat dikuasai siswa dengan baik. Fokus utamanya adalah kemampuan akademik (academic achievement), (Sanjaya 2007).

Dimyati \& Mujiono (2002) menyatakan bahwa pembelajaran ekspositori guru aktif memberikan penjelasan dan informasi terperinci tentang bahan pelajaran. Tujuan utamanya adalah "memindahkan" pengetahuan, keterampilan dan nilai - nilai kepada siswa. Peranan guru dalam pelajaran ini adalah : 1) penyusun program pelajaran, 2) pemberi informasi yang benar, 3) pemberi fasilitas pelajaran yang baik, 4) pembimbing siswa dalam pemerolehan informasi yang benar, dan 5) penilai pemerolehan informasi.

Slameto (2003) menyatakan dalam strategi ekspositori, guru menyajikan materi yang harus dipelajari, memberikan jawaban jawaban, manyajikan prinsip - prinsip dan mengelaborasikan seluruh isi yang harus dipelajari. Pengajaran disini merupakan proses mengajar deduktif, dimulai dengan pemberian definisi dari konsep, prinsip - prinsip yang akan diajar, menjelaskannya dan memberitahukan implikasi - implikasinya.

Sanjaya (2007) menyatakan bahwa terdapat beberapa karakteristik metode ekspositori, yaitu : (1) ekspositori dilakukan dengan cara menyampaikan materi pelajaran secara verbal, artinya bertutur secara lisan merupakan alat utama dalam melakukan strategi ini, oleh karena itu sering orang mengidentifikasinya dengan ceramah, (2) biasanya materi pelajarannya yang sudah jadi, seperti data atau fakta, konsep - konsep tertentu yang harus dihafal sehingga tidak menuntut siswa berfikir ulang, (3) tujuan utama pembelajaran adalah penguasaan materi pelajaran itu sendiri, artinya setelah proses 
pembelajaran berakhir siswa diharapkan dapat memahaminya dengan benar dengan cara dapat mengungkapkan kembali materi yang telah diuraikan.

Dalam komunikasi dengan orang lain, tidak saja dituntut untuk menguasai gramatika dari suatu bangsa, tetapi juga dibutuhkan pengetahuan dalam berkomunikasi dengan orang lain yang disebut juga komunikasi interpersonal. Menurut Muhammad (2004) komunikasi interpersonal merupakan proses pertukaran informasi di antara seseorang dengan paling kurang seorang lainnya atau biasanya di antara dua orang yang dapat langsung diketahui baliknya. Menurut Devito (2002:13) komunikasi interpersonal adalah penyampaian pesan oleh satu orang dan penerimaan pesan oleh orang lain atau sekelompok kecil orang, dengan berbagai dampaknya dan dengan peluang untuk memberikan umpan balik segera, sedangkan Mulyana (2000) menyatakan bahwa komunikasi interpersonal adalah komunikasi antara orangorang secara tatap muka, yang memungkinkan setiap pesertanya menangkap reaksi orang lain secara langsung, baik secara verbal atau nonverbal. Komunikasi interpersonal ini adalah komunikasi yang hanya dua orang, seperti suami istri, dua sejawat, dua sahabat dekat, guru-murid dan sebagainya. Dari berbagai pendapat para ahli tentang pengertian komunikasi interpersonal, Effendy (2003) menyimpulkan pada hakekatnya komunikasi interpersonal adalah komunikator dengan komunikan, komunikasi jenis ini dianggap paling efektif dalam upaya mengubah sikap, pendapat atau perilaku seseorang, karena sifatnya yang dialogis berupa percakapan. Arus balik bersifat langsung, komunikator mengetahui tanggapan komunikasi ketika itu juga.

West dan Turner (2008) menyatakan komunikasi interpersonal merujuk pada komunikasi yang terjadi secara langsung antara dua orang, konteks interpersonal banyak membahas tentang bagaimana suatu hubungan dimulai, mempertahankan suatu hubungan, dan keretakan suatu hubungan. Pada saat komunikasi dilancarkan, komunikator mengetahui secara pasti apakah komunikasinya positif atau negatif, berhasil atau tidaknya, jika ia dapat memberikan kesempatan pada komunikan untuk bertanya seluas-luasnya. Komunikasi interpersonal menuntut berkomunikasi dengan orang lain. Komunikasi jenis ini dibagi lagi menjadi komunikasi didik, komunikasi publik, dan komunikasi kelompok kecil (Rahmad, 2001)

Komunikasi interpersonal juga berlaku secara kontekstual bergantung kepada keadaan, budaya, dan juga konteks psikologikal. Cara dan bentuk interaksi antara individu akan tercorak mengikuti keadaan-keadaan ini. Rahmad (2001) menjelaskan bahwa salah satu sistem dalam komunikasi interpersonal adalah hubungan interpersonal. Komunikasi yang efektif ditandai dengan hubungan interpersonal yang baik. Kegagalan komunikasi sekunder terjadi, bila isi pesan kita pahami, tetapi hubungan di antara komunikan menjadi rusak. Untuk menumbuhkan dna meningkatkan hubungan interpersonal, kita perlu meningkatkan kualitas komunikasi.

Devito (2002) menjelaskan bahwa komunikasi interpersonal akan efektif bila memenuhi aspek-aspek: (1) keterbukaan yang merupakan aspek dari komunikasi interpersonal yang menunjukkan keinginan untuk terbuka bagi setiap orang yang berinteraksi dengan orang lain, (2) empati, merupakan aspek dari komunikasi interpersonal yang berkaitan dengan merasakan sebagaimana yang dirasakan oleh orang lain yakni mencoba merasakan dalam cara yang sama dengan orang lain, (3) dukungan, merupakan aspek dari komunikasi interpersonal yang berkaitan dengan pemberian dukungan yang berbentuk ucapan maupun gerakan, (4) kepositifan, merupakan aspek komunikasi interpersonal yang berkaitan dengan perhatian positif terhadap diri seseorang, dan (5) kesamaan, merupakan aspek komunikasi interpersonal yang menyatakan pada hakekatnya manusia tidak ada yang sama sekalipun kembar dapat dilihatr perbedaanperbedaannya, oleh karena itu komunikasi interpersonal akan efektif apabila individuindividu yang berkomunikasi itu dalam suasana kesamaan.

Rahmad (2001) menyatakan salah satu hal yang penting dalam komunikasi interpersonal adalah kepercayaan pada orang lain. Percayaan pada orang lain akan tumbuh bila ada faktor-faktor sebagai berikut: (1) karakteristik dan maksud orang lain, artinya orang tersebut memiliki kemampuan, keterampilan, pengalaman dalam bidang tertentu, (2) hubungan kekuasaan, artinya apabila seseorang mempunyai kekuasaan terhadap orang lain, maka orang itu patuh dan tunduk, (3) kualitas komunikasi dan sifatnya 
mengambarkan adanya keterbukaan, bila maksud dan tujuan sudah jelas, harapan sudah dinyatakan, maka sikap percaya akan muncul.

Menurut Redding yang dikutip Muhammad (2004) mengembangkan klasifikasi komunikasi interpersonal menjadi: (1) interaksi intim, (2) percakapan sosial, interogasi atau pemeriksaan dan (3) wawancara. Interaksi intim termasuk komunikasi di antara teman baik, anggota famili, dan orang-orang yang sudah mempunyai ikatan emosional yang kuat. Percakapan sosial adalah interaksi untuk menyenangkan seseorang secara sederhana. Tipe komunikasi tatap muka penting bagi pengembangan hubungan informasi dalam organisasi. Misalnya dua orang atau lebih bersama-sama dan berbicara tentang perhatian, minat di luar organisasi seperti isu politik, teknologi dan lain sebagainya. Interogasi atau pemerikasaan adalah interaksi antara seseorang yang ada dalam kontrol, yang meminta atau bahkan menuntut informasi dari yang lain. Misalnya seorang karyawan dituduh mengambil barang-barang organisasi maka atasannya akan menginterogasinya untuk mengetahui kebenarannya. Wawancara adalah salah satu bentuk komunikasi interpersonal dimana dua orang terlibat dalam percakapan yang berupa tanya jawab. Misalnya atasan yang

Masalah penelitian ini adalah: (1) Apakah hasil belajar public relations mahasiswa yang diajarkan menggunakan strategi pembelajaran mind mapping lebih tinggi daripada hasil belajar mahasiswa yang diajarkan dengan menggunakan strategi pembelajaran ekspositori?; (2) Apakah hasil belajar public relations mahasiswa yang memiliki komunikasi interpersonal tinggi lebih tinggi daripada hasil belajar public relations mahasiswa yang memiliki komunikasi interpersonal rendah?; dan (3) Apakah ada interaksi antara strategi pembelajaran dengan komunikasi interpersonal terhadap hasil belajar public relations?

\section{METODE}

Populasi dalam penelitian ini adalah seluruh mahasiswa semester VI Fakultas Dakwah IAIN Padang Sidempuan yang terdiri dari 4 kelas. Dalam penelitian ini, sampel diambil dengan random sampling teknik undian. Dari empat kelas yang ada, dipilih 2 kelas secara random sebagai kelompok eksperimen dan kelompok kontrol. Kelas A yaitu sebagai kelas eksperimen dengan jumlah siswa 37 orang dan kelas B sebagai kelas kontrol dengan jumlah siswa 37 orang.

Penelitian ini menggunakan metode eksperimental semu (quasi-reksperimental research). Pada penelitian eksperimen murni kelompok subjek penelitian ditentukan secara acak, sehingga akan diperoleh kesetaraan kelompok yang berada dalam batas-batas fluktuasi acak.

Desain penelitian yang digunakan adalah desain faktorial $2 \times 2$. sebagai variabel bebas pertama yaitu strategi pembelajaran, dengan dua strategi yaitu strategi pembelajaran mind mapping dan strategi pembelajaran ekspositori. Variabel moderator yaitu komunikasi interpersonal, dengan pengelompokkan komunikasi interpersonal tinggi dan komunikasi interpersonal rendah. Sedangkan variabel terikatnya adalah hasil belajar public relations. Desain penelitian ini dapat dilihat pada tabel 1 berikut ini.

Tabel 1. Desain Faktorial 2 x 2

\begin{tabular}{|l|c|c|}
\hline \multicolumn{1}{|r|}{ Strategi Pembelajaran (A) } & Mind Mapping $\left(\mathrm{A}_{1}\right)$ & Ekspositori $\left(\mathrm{A}_{2}\right)$ \\
Komunikasi interpersonal & & $\mathrm{A}_{2} \mathrm{~B}_{1}$ \\
\hline Tinggi $\left(\mathrm{B}_{1}\right)$ & $\mathrm{A}_{1} \mathrm{~B}_{2}$ & $\mathrm{~A}_{2} \mathrm{~B}_{2}$ \\
\hline Rendah $\left(\mathrm{B}_{2}\right)$ & \\
\hline
\end{tabular}

Keterangan:

$$
\begin{aligned}
\mathrm{A}_{1} \mathrm{~B}_{1}= & \text { Hasil belajar public relations } \\
& \begin{array}{l}
\text { mahasiswa yang dibelajarkan } \\
\text { menggunakan strategi mind mapping }
\end{array} \\
& \text { pada mahasiswa dengan komunikasi } \\
& \text { interpersonal tinggi } \\
\mathrm{A}_{1} \mathrm{~B}_{2}= & \begin{array}{l}
\text { Hasil belajar public relations } \\
\text { mahasiswa yang dibelajarkan }
\end{array}
\end{aligned}
$$

menggunakan strategi mind mapping pada mahasiswa dengan komunikasi interpersonal rendah

$\mathrm{A}_{2} \mathrm{~B}_{1}=$ Hasil belajar public relations mahasiswa yang dibelajarkan menggunakan strategi ekspositori pada mahasiswa dengan komunikasi interpersonal tinggi 
$\begin{aligned} \mathrm{A}_{2} \mathrm{~B}_{2}= & \begin{array}{l}\text { Hasil belajar public relations } \\ \text { mahasiswa yang dibelajarkan }\end{array} \\ & \text { menggunakan strategi ekspositori } \\ & \text { pada mahasiswa dengan komunikasi } \\ & \text { interpersonal rendah }\end{aligned}$

Teknik analisis data dalam penelitian ini menggunakan analisis deskriptif dan analisis inferensial. Dalam menggunakan ANAVA dua jalur perlu dipenuhi beberapa syarat yaitu (1) data yang digunakan harus berdistribusi normal, maka dilakukan uji normalitas dengan menggunakan uji Lillifors, (2) data harus memiliki varians populasi homogen, maka harus dilakukan uji homogenitas varians dengan menggunakan uji Fisher dan uji Bartlet. Taraf signifikan yang digunakan dalam penelitian ini adalah $\alpha=0,05$. Adapun hipotesis dalam penelitian ini adalah sebagai berikut:
Hipotesis pertama:

$$
\begin{array}{ll}
\text { Ho } & : \mu_{\mathrm{A} 1} \leq \mu_{\mathrm{A} 2} \\
\mathrm{H} 1 & : \mu_{\mathrm{A} 1}>\mu_{\mathrm{A} 2}
\end{array}
$$

Hipotesis kedua:

$$
\begin{array}{ll}
\text { Ho } & : \mu_{\mathrm{B} 1} \leq \mu_{\mathrm{B} 2} \\
\mathrm{H} 1 & : \mu_{\mathrm{B} 1}>\mu_{\mathrm{B} 2}
\end{array}
$$

Hipotesis ketiga:

$$
\begin{aligned}
& \text { Ho : } \mathrm{A} \times \mathrm{B}=0 \\
& \mathrm{H} 1: \mathrm{A} \times \mathrm{B} \neq 0
\end{aligned}
$$

\section{HASIL DAN PEMBAHASAN \\ Hasil}

Untuk keperluan pengujian hipotesis dengan menggunakan teknik analisis anava faktorial 2 x 2 dan uji lanjut Scheffe diperlukan harga rata-rata tiap kelompok, berikut ini disajikan data hasil belajar public relations pada Tabel 2.

Tabel 2. Rangkuman Data Hasil Perhitungan Analisis Deskriptif

\begin{tabular}{|c|c|c|c|c|}
\hline \multicolumn{2}{|c|}{ Komunikasi Interpersonal } & \multicolumn{3}{c|}{ Strategi Pembelajaran } \\
\cline { 3 - 5 } \multicolumn{2}{|c|}{} & $\mathbf{A}_{\mathbf{1}}$ & $\mathbf{A}_{\mathbf{2}}$ & Total \\
\hline \multirow{3}{*}{ Tinggi $\left(\mathrm{B}_{1}\right)$} & $\mathrm{N}$ & 19 & 19 & 38 \\
& $\sum \mathrm{X}$ & 871 & 757 & 1628 \\
& $\sum \mathrm{X}^{2}$ & 40073 & 30379 & 70452 \\
& $\bar{X}$ & 45,34 & 39,84 & 42,84 \\
\hline \multirow{3}{*}{ Rendah $\left(\mathrm{B}_{2}\right)$} & $\mathrm{N}$ & 18 & 18 & 36 \\
& $\sum \mathrm{X}$ & 645 & 673 & 1318 \\
& $\sum \mathrm{X}^{2}$ & 23423 & 25437 & 48860 \\
& $\bar{X}$ & 35,83 & 37,39 & 36,61 \\
\hline \multirow{3}{*}{ Total } & $\mathrm{N}$ & 37 & 37 & 74 \\
& $\sum \mathrm{X}$ & 1516 & 1430 & 2946 \\
& $\sum \mathrm{X}^{2}$ & 63496 & 55816 & 119312 \\
& $\bar{X}$ & 40,97 & 38,65 & 39,81 \\
\hline
\end{tabular}

Setelah data diolah dengan anava 2 jalur 2 × 2 maka diperoleh hasil analisis seperti pada tabel 3

Tabel 3. Ringkasan Hasil Perhitungan ANAVA Faktorial 2 x 2

\begin{tabular}{|l|c|r|r|r|r|r|}
\hline \multicolumn{1}{|c|}{ Sumber Variasi } & Dk & \multicolumn{1}{c|}{ JK } & \multicolumn{1}{c|}{ RJK } & F $_{\text {hitung }}$ & $\begin{array}{c}\mathrm{F}_{\text {tabel }} \\
\alpha=0,05\end{array}$ & Keterangan \\
\hline Strategi pembelajaran (A) & 1 & 91,95 & 91,95 & 6,79 & 3,98 & Signifikan \\
Komunikasi Irterpersonal (B) & 1 & 717,74 & 717,74 & 53,01 & 3,98 & Signifikan \\
Interaksi (AB) & 1 & 263,83 & 263,83 & 19,48 & 3,98 & Signifikan \\
Galat & 70 & 947,83 & 13,54 & & & \\
\hline & 74 & 2029,35 & & & & \\
\hline
\end{tabular}

Dengan kata lain semakin baik strategi pembelajaran yang diterapkan oleh dosen dalam menyampaikan bahan ajar, maka semakin tinggi pencapaian hasil belajarnya. Di lain pihak faktor komunikasi interpersonal belajar perlu diperhatikan karena terbukti bahwa komunikasi interpersonal berpengaruh terhadap hasil belajar public relations. Hasil pengujian dengan menggunakan Scheffe dapat dilihat dalam Tabel 4. berikut 
Tabel 4. Ringkasan Hasil Pengujian dengan Menggunakan Uji Scheffe

\begin{tabular}{|c|c|c|c|}
\hline No & Hipotesis Statistik & $F_{\text {hitung }}$ & $F_{\text {tabel }} \alpha=0,05$ \\
\hline 1 & $\begin{array}{c}\text { Ho }: \mu \mathrm{A}_{1} B_{1}=\mu \mathrm{A}_{2} \mathrm{~B}_{1} \\
\mathrm{Ha}: \mu \mathrm{A}_{1} \mathrm{~B}_{1}>\mu \mathrm{A}_{2} \mathrm{~B}_{1}\end{array}$ & $25,26^{*}$ & 2,85 \\
\hline 2 & $\begin{array}{l}\mathrm{Ho}: \mu \mathrm{A}_{1} \mathrm{~B}_{1}=\mu \mathrm{A}_{1} \mathrm{~B}_{2} \\
\mathrm{Ha}: \mu \mathrm{A}_{1} \mathrm{~B}_{1}>\mu \mathrm{A}_{1} \mathrm{~B}_{2}\end{array}$ & $68,39^{*}$ & 2,86 \\
\hline 3 & $\begin{array}{l}\mathrm{Ho}: \mu \mathrm{A}_{1} \mathrm{~B}_{1}=\mu \mathrm{A}_{2} \mathrm{~B}_{2} \\
\mathrm{Ha}: \mu \mathrm{A}_{1} \mathrm{~B}_{1}>\mu \mathrm{A}_{2} \mathrm{~B}_{2}\end{array}$ & $48,78^{*}$ & 2,86 \\
\hline 4 & $\begin{array}{l}\mathrm{Ho}: \mu \mathrm{A}_{1} \mathrm{~B}_{2}=\mu \mathrm{A}_{2} \mathrm{~B}_{1} \\
\mathrm{Ha}: \mu \mathrm{A}_{1} \mathrm{~B}_{2}>\mu \mathrm{A}_{2} \mathrm{~B}_{1}\end{array}$ & $10,97^{*}$ & 2,86 \\
\hline 5 & $\begin{array}{l}\mathrm{Ho}: \mu \mathrm{A}_{1} \mathrm{~B}_{2}=\mu \mathrm{A}_{2} \mathrm{~B}_{2} \\
\mathrm{Ha}: \mu \mathrm{A}_{1} \mathrm{~B}_{2}>\mu \mathrm{A}_{2} \mathrm{~B}_{2}\end{array}$ & 1,61 & 2,87 \\
\hline 6 & $\begin{array}{l}\mathrm{Ho}: \mu \mathrm{A}_{2} \mathrm{~B}_{1}=\mu \mathrm{A}_{2} \mathrm{~B}_{2} \\
\mathrm{Ha}: \mu \mathrm{A}_{2} \mathrm{~B}_{1}>\mu \mathrm{A}_{2} \mathrm{~B}_{2}\end{array}$ & $4,11^{*}$ & 2,86 \\
\hline
\end{tabular}

Keterangan : $*$ signifikan

Untuk memvisualisasikan interaksi dan strategi pembelajaran dan komunikasi interpersonal terhadap hasil belajar public relations mahasiswa IAIN Padang Sidempuan, maka di ambil dari rata-rata dari tiap kelompok data penelitian, dapat digambarkan sebagai berikut pada gambar 1.

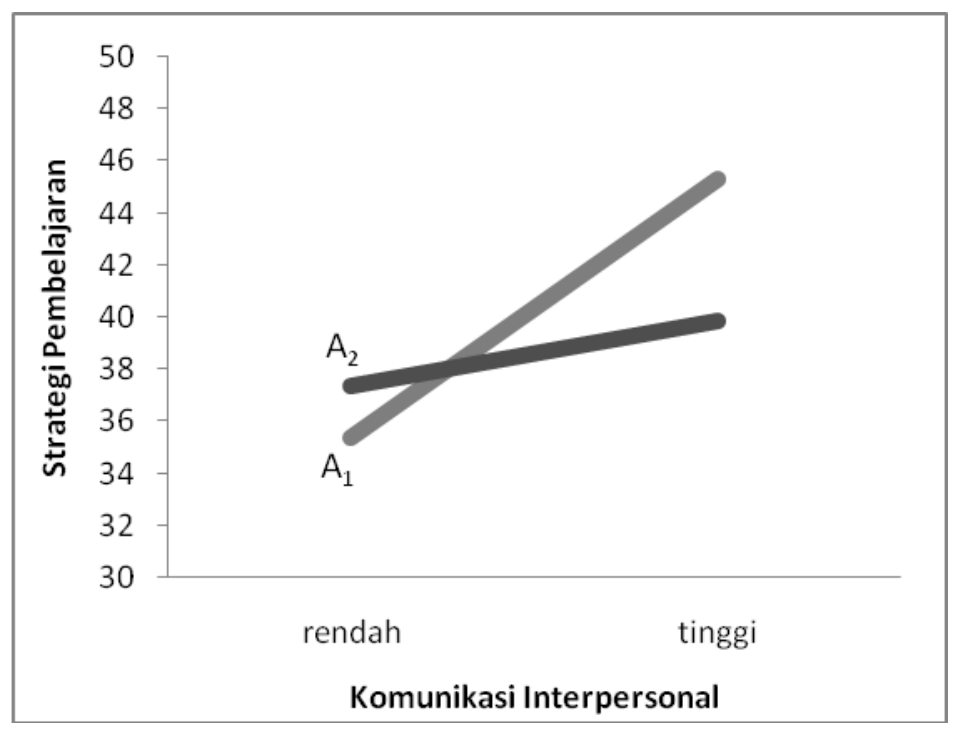

Gambar 1. Interaksi Strategi Pembelajaran dan Komunikasi Interpersonal Terhadap Hasil Belajar Public Relations Mahasiswa

\section{Pembahasan}

Strategi pembelajaran mindmapping adalah strategi pembelajaran yang menggunakan diagram untuk menampilkan kata, gagasan, tugas atau hal yang lain yang saling dihubungkan satu sama lain dan disusun secara radial di sekitar kata/gagasan kunci. Mind mapping melibatkan kedua sisi otak karena menggunakan gambar, warna, imajinasi (wilayah otak kanan) bersamaan dengan kata, angka dan logika (wilayah otak kiri). Semua gagasan dalam mind mapping berkaitan, membantu otak membuat lompatan pengertian dan imajinasi besar melalui asosiasi (Buzan
2011:60). Mind mapping membantu kita belajar, menyusun, menyimpan sebanyak mungkin informasi, mengelompokkannya dengan cara alami, memberi kita akses mudah dan langsung ( ingatan yang sempurna pada apapun yang kita pelajari). Mind mapping bertujuan membuat materi pelajaran terpola secara visual dan grafis yang akhirnya dapat membantu merekam, memperkuat, dan mengingat kembali informasi yang telah dipelajari. Tujuan pelaksanaan pembelajaran mind mapping adalah membina mahasiswa dalam rangka mengembangkan aspek kognitif, afektif dan psikomotorik mahasiswa secara 
komprehensif berkomunikasi menyampaikan $\begin{array}{cr}\text { (menyeluruh) dan } \\ \text { secara } & \text { efektif } \\ \text { esensi } & \text { dakwah }\end{array}$ mampu dalam dengan masyarakat

Hasil penelitian Dahnia (2011) tentang Pengaruh penggunaan model pembelajaran mind mapping terhadap hasil belajar akuntansi , menyimpulkan bahwa ada pengaruh dari penggunaan model pembelajaran mind mapping terhadap hasil belajar akuntansi. Pembelajaran dengan strategi pembelajaran mind mapping , dosen berperan sebagai fasilitator yaitu pengarah dan pembimbing, yakni membimbing mahasiswa dalam menemukan konsep dan menggambarkan pengantar materi. Sedangkan mahasiswa memegang peranan sangat penting dan harus berkerja secara aktif dalam hal berpikir dan mencatat materi ajar yang digambarkan sekilas oleh dosen. Hal ini diharapkan ingatan siswa dalam menemukan konsep dan mengingat teori akan lebih tahan lama karena mahasiswa secara mandiri menggambarkan mapping atau peta pikiran secara kreatif dengan symbol, gambar, dan memberikan warna sesuai materi ajar. Setelah mahasiswa mampu mencatat dengan kreativitas sendiri, maka mahasiswa tersebut akan mampu mengingat materi tersebut untuk disampaikan ulang dengan bahasa sendiri yang lebih mereka kuasai sesuai dengan tujuan mata kuliah public relations.

Strategi pembelajaran mind mapppng dapat meningkatkan hasil belajar karena strategi pembelajaran mind mapping mampu membuat mahasiswa menemukan konsep dan mengingat teori, dan jawaban sehingga dalam menyelesaikan permasalahan public relations dapat dikerjakan dan dianalisa dengan cepat dan akurat dan akhirnya berpengaruh pada hasil belajar mahasiswa. Dengan menggunakaan strategi pembelajaran mind mapping mahasiswa tidak akan mengalami kesulitan dalam mengingat materi dan menyampaikan ulang kembali.. Pembelajaran dimana mahasiswa menemukan sendiri cara mudah untuk mengingat materi ajar dan yang akan disampaikan. Pada pembelajaran mind mapping ini juga mahasiswa menjadi mahasiswa yang lebih aktif dan kreatif, mengingat belajar akan lebih bermakna jika fungsi kognitif, afektif, dan psikomotorik dapat berkerja bersama-sama.

Sedangkan strategi pembelajaran ekspositori adalah strategi pembelajaran yang didesain dengan menempatkan dosen sebagai sumber utama belajar dan sekaligus sebagai penyaji isi pelajaran karena dosen telah mengelola dan mempersiapkan bahan ajaran hingga tuntas dan menyajikan bahan pelajaran secara utuh atau menyeluruh, lengkap, sistematis, dengan penyampaian secara verbal. Hal ini menyebabkan pada strategi ini dosen harus menjadi lebih aktif dan gurulah yang lebih berperan dominan. Pembelajaran ekspositori (expository learning) sama dengan pembelajaran yang terjadi dengan belajar menerima. Strategi pembelajaran ekspositori merupakan bentuk dari pendekatan pembelajaran yang berorientasi kepada dosen, peranan dosen dalam proses pembelajaran sangat dominan. Slameto (2003) menyatakan dalam strategi ekspositori, dosen menyajikan materi yang harus dipelajari, memberikan jawaban - jawaban, menyajikan prinsip prinsip dan mengelaborasikan seluruh isi yang harus dipelajari. Pengajaran disini merupakan proses mengajar deduktif, dimulai dengan pemberian definisi dari konsep, prinsip prinsip yang akan diajar, menjelaskannya dan memberitahukan implikasi - implikasinya.

Strategi pembelajaran ekspositori adalah strategi pembelajaran yang didesain dengan menempatkan dosen sebagai sumber utama belajar dan sekaligus sebagai penyaji isi pelajaran karena dosen telah mengelola dan mempersiapkan bahan ajaran hingga tuntas dan menyajikan bahan pelajaran secara utuh atau menyeluruh, lengkap, sistematis, dengan penyampaian secara verbal. Hal ini menyebabkan pada strategi ini dosen harus menjadi lebih aktif dan dosenlah yang lebih berperan dominan. Pembelajaran ekspositori (expository learning) sama dengan pembelajaran yang terjadi dengan belajar menerima. Strategi pembelajaran ekspositori merupakan bentuk dari pendekatan pembelajaran yang berorientasi kepada dosen, peranan dosen dalam proses pembelajaran sangat dominan. Dosen menyampaikan materi secara terstruktur dengan harapan materi pelajaran yang disampaikan dapat dikuasai mahasiswa dengan baik.

Dengan menerapkan strategi pembelajaran mind mapping mahasiswa akan lebih tertarik dan termotivasi pada setiap materi yang diajarkan, karena adanya simbol, gambar, dan informasi yang diberikan oleh dosen, sehingga akan memperkuat ingatan mahasiswa tentang materi yang diajarkan. Mampu membuat mahasiswa semangat dalam belajar karena adanya gambar-gambar,simbol, dan 
memberikan warna sesuai materi ajar dalam proses pembelajaran. Dengan strategi pembelajaran mind mapping mampu meningkatkan hasil belajar public relations mahasiswa IAIN Padang Sidempuan.

Hasil penelitian menunjukkan bahwa hasil belajar public relations mahasiswa yang memiliki komunikasi interpersonal tinggi lebih tinggi dari pada hasil belajar public relations mahasiswa yang memiliki komunikasi interpersonal rendah. Komunikasi interpersonal tinggi lebih mampu memahami materi public relations dibandingkan mahasiswa yang memiliki komunikasi interpersonal rendah.

Menurut Devito (2002:13) komunikasi interpersonal adalah penyampaian pesan oleh satu orang dan penerimaan pesan oleh orang lain atau sekelompok kecil orang, dengan berbagai dampaknya dan dengan peluang untuk memberikan umpan balik segera. Komunikasi interpersonal memberikan kesempatan kepada manusia untuk berbicara tentang apa yang disukai, atau mengenai dirinya. Adalah sangat menarik dan mengasyikkan bila berdiskusi mengenai perasaan, pikiran, dan tingkah laku diri sendiri dengan orang lain. Dengan membicarakan diri kita dengan orang lain, memberikan sumber balikan yang luar biasa pada perasaan, pikiran, dan tingkah laku seseorang. Banyak informasi yang diketahui datang dari komunikasi interpersonal, meskipun banyak jumlah informasi yang datang dari media massa hal itu seringkali didiskusikan dan akhirnya dipelajari atau didalami melalui interaksi interpersonal. Komunikasi interpersonal sangat dibutuhkan dalam rangka berkomunikasi dengan orang lain, namun tidak selamanya seseorang memiliki kemampuan berkomunikasi dengan orang lain secara baik. Adakalanya seseorang dapat dengan mudah menyampaikan. Keinginannya dan mempengaruhi orang lain sehingga orang lain mau melakukan apa yang diinginkannya, tetapi ada pula orang yang kurang atau bahkan sama sekali tidak memiliki karakteristik kemampuan berkomunikasi interpersonal ini, akibatnya orang tersebut akan mengalami kesulitan dalam berkomunikasi dengan orang lain.

Dalam mengikuti pembelajaran public relations, mahasiswa memiliki komunikasi interpersonal yang berbeda-beda, misalnya kemampuan komunikasi interpersonal antara mahasiswa yang satu akan berbeda dengan kemampuan interpersonal mahasiswa yang lain. Mahasiswa yang memiliki kemampuan komunikasi interpersonal yang tinggi akan lebih mudah mengolah informasi dan mengemukakan ide dan pemikiran yang ada dibenaknya bila dibandingkan dengan mahasiswa yang memiliki kemampuan komunikasi komunikasi interpersonal rendah.

Ketika mahasiswa yang mempunyai kemampuan komunikasi interpersonal tinggi diberikan pembelajaran dengan tekhnik mencatat yang kreatif dan mampu melibatkan seluruh potensi kerja otaknya maka hal ini akan memungkinkan mahasiswa mengingat secara kuat materi dan mampu menyampaikan gagasan dan ide serta mengembangkannya sesuai kebutuhan masyarakat untuk mencapai tujuan dakwah . Mahasiswa yang memiliki komunikasi interpersonal yang tinggi juga akan lebih mudah dalam belajar, karena hal-hal yang dipelajari dalam public relations adalah konsep-konsep menjalin hubungan yang baik dan berkomunikasi secara efektif dalam menyampaikan visi dan misi dakwah sehingga berkomunikasi interpersonal menjadi urgen. Hal sebaliknya akan terjadi berbeda pada mahasiswa yang memiliki komunikasi interpersonal yang rendah akan mengalami kesulitan dalam hal mempelajari public relations. Mahasiswa yang memiliki komunikasi interpersonal yang tinggi juga relatif akan lebih mudah mengolah informasi dalam mengemukakan ide dan pemikiran yang ada dibenaknya bila dibandingkan dengan mahasiswa yang memiliki komunikasi interpersonal rendah. Mahasiswa yang memiliki komunikasi interpersonal yang rendah kurang mampu berkomunikasi dengan orang lain, dan memelihara hubungan dengan orang. Mahasiswa yang memiliki komunikasi interpersonal tinggi menggunakan konsep dalam menganalisis suatu informasi bersifat logis, rasional dan intelektual. Mahasiswa yang komunikasi interpersonal tinggi lebih suka terlibat dalam pembelajaran dan selalu ingin mengetahui sebab-sebab dari suatu persoalan sedangkanmahasiswa yang komunikasi interpersonalnya rendah mengupayakan bantuan dan arahan dari orang lain. Dengan kata lain, mahasiswa yang komunikasi interpersonal rendah tidak siap kalau belajar menemukan sendiri cenderung suka belajar mengandalkan kelompok. Mereka tidak berusaha mendapatkan kesempurnaan dari pekerjaan mereka tahap demi tahap.

Pentingnya suatu strategi dalam konteks belajar mengajar yaitu pola umum perbuatan 
dosen dan mahasiswa di dalam perwujudan kegiatan belajar mengajar yang bertujuan sebagai kerangka acuan untuk pemahaman lebih baik, yang pada gilirannya untuk dapat memilih secara tetap serta menggunakannya secara efektif di dalam penciptaan sistem belajar mengajar. Terciptanya sistem pembelajaran dipengaruhi oleh strategi pembelajaran yang dapat membangkitkan atau mendorong timbulnya aktifitas mahasiswa dalam proses pembelajaran dan menjadi peningkatan kemampuan mahasiswa untuk memahami materi pembelajaran serta prestasi belajar mahasiswa. Dengan demikian dapat dipahami bahwa tujuan pembelajaran mempengaruhi mahasiswa agar belajar atau membelajarkan mahamahasiswa. Dari suatu proses pembelajaran, siswa akan memperoleh manfaat antara lain: a) belajar tentang sesuatu yang tidak akan diperoleh tanpa proses pembelajaran, b) mampu untuk mempelajari sesuatu dengan cara efektif dan efisien. Dengan adanya strategi pembelajaran yang diterapkan oleh dosen diharapkan mahasiswa akhirnya mempunyai sikap untuk belajar lebih sungguh terhadap pembelajaran.Untuk meningkatkan hasil belajar public relations dibutuhkan suatu strategi pembelajaran yang relevan.

Strategi pembelajaran mind mapping merupakan strategi pembelajaran yang menuntut mahasiswa untuk mampu menggunakan tekhnik mencatat dengan membuat peta pikiran materi melalui berbagai sumber dengan menggunakan tulisan, gambar, symbol, warna. Mind mapping memandu agar mahasiswa menggunakan seluruh kreativitas dalam berpikir melalui peta yang mereka buat. Sehingga pada akhirnya materi yang dibahas akan tinggal lama dalam long term memory mahasiswa. Materi yang selama ini cenderung membosankan untuk diingat, akan dibuat seringkas mungkin dengan tulisan, gambar atau symbol yang mewakilinya. Mahasiswa bebas dalam mengekspresikan pikiran dengan kreativitas mereka, dan nantinya akan mampu untuk menyampaikan dan menjabarkan kembali peta pikiran tersebut dengan bahasanya sendiri baik didepan kelas ataupun nantinya ditengahtengah masyarakat. Dosen dan mahasiswa, serta mahasiswa dengan mahasiswa. Dosen berperan sebagai fasilitator, sedangkan mahasiswa bebas mengkomunikasikan pikirannya tanpa harus takut salah. Dengan jalan seperti ini maka mahasiswa akan lebih mudah untuk menguasai komunikasi interpersonal dalam public relations, makin tinggi komunikasi interpersonal maka hasil belajar public relations yang diharapkan pun akan semakin baik pula, hal ini terjadi karena komunikasi interpersonal yang telah tersimpan di dalam long term memory mahasiswa dapat difungsikan atau dipergunakan dalam proses berkomunikasi. Sebaliknya, makin sedikit komunikasi interpersonal, maka makin sulit bagi mahasiswa untuk melakukan proses komunikasi dan secara otomatis hasil yang belajar yang diperoleh tidak sesuai dengan apa yang diharapkan.

Pembelajaran dengan menggunakan strategi mind mapping, dapat memberikan peluang besar bagi mahasiswa dalam mengembangkan kemampuanya untuk berkomunikasi terhadap mahasiswa yang memiliki komunikasi interpersonal tinggi, karena strategi mind mapping menuntut mahasiswa untuk lebih aktif dan kreatif dalam mengingat dan menjabarkan materi yang akan disampaikan.

Hal sebaliknya, jika pembelajaran dengan menggunakan strategi ekspositori, mahasiswa yang mempunyai komunikasi interpersonal tinggi akan membuat penalarannya tidak mengalami perkembangan dan tidak akan aktif dalam proses pembelajaran karena dibatasi oleh peran dosen yang lebih mendominasi pembelajaran. Dosen menyampaikan materi searah, tanpa memberikan kesempatan kepada mahasiswa untuk membuat catatan kreatif dalam pikiran mereka. Hanya mencatat sekedarnya saja, sehingga materi akan sulit diingat dan dikomunikasikan kembali dan pembelajaran terasa membosankan bagi mahasiswa. Hal ini mengakibatkan wawasan mahasiswa tidak mengalami perkembangan dalam hal memahami dan mempraktekkan kembali public relations.

Sementara itu, mahasiswa yang memiliki komunikasi interpersonal rendah akan memperoleh hasil belajar yang lebih tinggi jika diajar dengan strategi ekspositori dibandingkan siswa yang mempunyai komunikasi interpersonal rendah yang diajar dengan strategi mind mapping. Hal ini dapat dipahami karena mahasiswa yang mempunyai komunikasi interpersonal rendah yang diajar dengan strategi ekspositori akan lebih giat belajar karena dengan adanya penjelasan dosen yang terperinci dan lebih struktural dalam menyampaikan bahan pelajaran. Mahasiswa yang mempunyai 
komunikasi interpersonal rendah yang diajar dengan strategi mind mapping kurang mampu menyesuaikan diri terhadap percepatan belajar siswa yang memiliki komunikasi interpersonal tinggi.

Selain itu, mahasiswa yang mempunyai komunikasi interpersonal rendah pada pembelajaran mind mapping semakin pasif karena ketidakmampuannya menyesuaikan diri di dalam proses pembelajaran. Hal ini disebabkan ruang geraknya dibatasi oleh temantemannya yang mempunyai komunikasi interpersonal tinggi, karena mahasiswa yang memiliki komunikasi interpersonal tinggi akan lebih aktif dan lebih mendominasi selama proses pembelajaran berlangsung.

Komunikasi interpersonal mahasiswa juga sangat mempengaruhi hasil belajar mahasiswa tersebut, mahasiswa yang memiliki kecerdasan linguistik tinggi akan memiliki hasil belajar yang tinggi dan namun sebaliknya, mahasiswa yang memiliki Komunikasi interpersonal rendah akan memiliki hasil belajar yang rendah, dikarenakan ketidakmampuan untuk mengembangkan dan memahami teks.

Sedangkan pada pembelajaran dengan strategi pembelajaran ekspositori peran dosen sangat dominan, mahasiswa mendapatkan bimbingan yang lebih rinci. Dosen akan lebih banyak memberikan informasi-informasi sedangkan mahasiswa sebagai pendengar yang secara seksama akan merekam dan menyimak penjelasan yang diberikan dosen. Keterlibatan fisik dan mental serta emosional mahasiswa diharapkan dapat diperkenalkan pada suatu cara atau kondisi pembelajaran yang dapat menumbuhkan rasa percaya diri dan juga perilaku yang inovatif dan kreatif. Dengan demikian mahasiswa yang mempunyai komunikasi interpersonal rendah akan lebih baik bila diajarkan dengan strategi pembelajaran ekspositori.

Meskipun strategi pembelajaran mind mapping lebih baik digunakan bagi mahasiswa yang memiliki komunikasi interpersonal tinggi, namun tidak tertutup kemungkinan dapat juga dipakai oleh siswa yang memiliki kemampuan interpersonal rendah. Hal ini disebabkan melalui strategi pembelajaran mind mapping mahasiswa dapat mengikuti pembelajaran dengan menyenangkan dan tidak membosankan

\section{PENUTUP \\ Simpulan}

Berdasarkan hasil penelitian dan pembahasan yang telah dikemukakan sebelumnya, maka dapat disimpulkan

1. Hasil Belajar Public Relations Mahasiswa yang Diajarkan Menggunakan Strategi Pembelajaran Mind Mapping Lebih Tinggi daripada Mahasiswa dan Strategi Pembelajaran Ekspositori

2. Hasil belajar public relations mahasiswa yang memiliki komunikasi interpersonal tinggi lebih tinggi daripada hasil belajar public relations mahasiswa yang memiliki komunikasi interpersonal rendah

3. Terdapat interaksi antara strategi pembelajaran dan komunikasi interpersonal terhadap hasil belajar public relations mahasiswa IAIN Padang Sidempuan

\section{Saran}

Beradasarkan simpulan dan implikasi seperti yang telah dikemukakan, maka disarankan beberapa hal berikut ini :

1. Para dosen disarankan untuk menggunakan strategi pembelajaran mind mapping sebagai strategi belajar alternatif dalam pembelajaran public relations

2. Para Dosen perlu memperhatikan kemampuan interpersonal mahasiswa yang merupakan aspek kognitif memberikan pengaruh yang besar terhadap hasil belajar mahasiswa

3. Penerapan strategi pembelajaran yang sesuai dengan karakteristik mahasiswa dan karakteristik mata pelajaran sangat mempengaruhi hasil belajar mahasiswa. Maka dosen perlu merancang dan mengembangkan strategi pembelajaran yang berkaitan dengan Public Relations.

4. Untuk kesempurnaan penelitiaan ini, disarankan kepada peneliti untuk mengadakan penelitian lanjutan dengan melibatkan variabel moderator lain seperti IQ, gaya belajar, motivasi, dan lain-lain. Perlu juga menambah populasi dan sampel yang lebih besar lagi, untuk mengecilkan tingkat kesalahan dan meningkatkan ketelitian hasil dari penelitian

\section{DAFTAR PUSTAKA}

Lubis, Asnarni. 2011. Penggunaan Media Mind Mapping dalam Proses Pembelajaran Strategi Preview, Question, Read, Reflect,recite, and Review( PQ4R) 
Terhadap Daya Ingat dan Hasil Belajar Kimia Peserta Didik. Tesis . Program Pascasarjana Universitas Negeri Medan

Buzan, Tony ( 2006). Buku Pintar Mind Map. Jakarta : Gramedia Pustaka Utama.

Dick, W. and Carey,L. 1996. The Systematic Design of Instructions. Fouth Edition. New York : Harper Collin College Publisher

Djamarah, S.B. dan Zain, A.2002. Strategi Belajar Mengajar. Jakarta : Rineka Cipta

Gagne, R.M.\& Briggs, L.J. 1979. Principles of Instructional Design. New York : Holt Rinehart and Winston

Hamalik, O.2004. Proses Belajar Mengajar. Jakarta : Bumi Aksara

Hayon, Josep, M.Hum, Drs. 2003. Membaca dan Menulis Wacana. Jakarta: Storia Grafika

Tampubolon, Hotnaria. 2011.Pengaruh Penggunaan Peta Konsep Berbasis Komputer terhadap Motivasi dan Hasil Belajar Kimia Mahasiswa Prodi Matematika FKIP UHN Pematang Siantar pada Pembelajaran Larutan.Tesis .Program Pascasarjana Universitas Negeri Medan

Lie, A. 2004. Cooperative Learning ( Mempraktikkan Cooperative Learning di Ruang-Ruang Kelas ). Jakarta : Grasindo

Merill, M.D. 1981. A Lesson Based on the Component Display Theory. New Jersey : Lawrence Erlbaum Ass.
Muhammad, A. 2007. Komunikasi Organisasi. Jakarta : Bumi Aksara

Mulyana, D. (2002). Ilmu Komunikasi Suatu Pengantar. Bandung: Remaja Rosdakarya

Mulyati.2005. Psikologi Belajar. Yogyakarta : Andi

Nasir, Moh. 2003. Metodologi Penelitian. Jakarta : Angkasa.

Reigeluth, C.M. 1983. Instructional Design Theories and Models : An Overview

of Their Current Status, Instructional Design: What is It and Why is it?, New Jersey : Publisher Hilsdale

Romizowski, A.Z. 1981. Designing Instructional System. New York : Nichol Publishing Company

Sanjaya, W. 2007. Srategi Pembelajaran Berorientasi Standar Proses Pendidikan. Jakarta : Kencana Prenada Media Group

Seels, B.C and Richey, R.C. 1994. Instructional TTechnology, The Defenition and Domains of the Field, Washington. Terjemahan. Yusuf Hadi Miarso dkk

Sudjana, N. 2002. Dasar-Dasar Proses Belajar Mengajar. Jakarta : Sinar Baru Algesindo

Sudijono, Anas. 2004. Pengantar Statistik Pendidikan. Jakarta: PT. Raja Grafindo Persada.

Trianto. 2007. Model-model Pembelajaran Inovatif Beroeientasi Konstruktivisme. Jakarta: Prestasi Pustaka Publisher 